〔第48回総会シンポジウム 一医療における高速現像処理一〕

2. 胸部 X線写真の臨床評価をめぐって

伊 藤 春 海

京都大学医学部附属病院放射線部

Key words: Chest radiograph CT radiology-pathology correlation

\title{
FACTORS INFLUENCING QUALITY AND USEFULNESS OF CHEST RADIOGRAPH
}

\author{
HaRumi Itoh, M.D. \& Dr. Sci. \\ Clinical Radiology Service Kyoto University Hospital
}

\section{Summary}

This article summarizes development of chest radiology in Japan. The general feature of chest radiology in Japan is characterized by extensive correlative studies between lung specimens and clinical radiologic images such as chest radiograph, tomograph and recent CT. Bofore 1960's pulmonary tuberculosis and silicosis were the major diseases. Despite limited quality of chest radiograph these diseases were diagnosed correctly because of inherent higher contrast of pathologic lesions. In the next 20 years until the end of 1970's both lung cancer and diffuse lung diseases other than tuberculosis and silicosis were the major concern in our society. For lung cancer higher $\mathrm{kV}$ radiograph was recommended to expand visibility of lung parenchyma and airways behind bone and mediastinum. Conventional tomography was used extensively to diagnose a nodule and malignant features of pulmonary vessels and bronchi related to the tumor. The role of tomography was established by correlation with surgically resected lung specimens. In contrast, tomography was not useful for diffuse lung diseases. A big gap was noticed between chest radiograph and histology. This problem has been solved to some extent by high resolution CT which was applied to diffuse lung diseases in Japan in 1979. Since then extensive correltaive studies have been performed between CT and inflated lung specimens, and CT has proven to be closer to macroscopic findings of inflated lung specimens. High resolution CT has revealed summation effect and relatively poor contrast resolution are the major problem to be solved in chest radiography of diffuse lung diseases.

\section{I .はじめに}

胸部X線写真に対する臨床評価は以下の 3 つの技術的 進歩に支えられて来た。

(1) 撮影機器, 感光材料

(2) 撮影技術

(3) 読影技術

（1)はメーカー，(2)は放射線技師，(3)は医師によって主
として担当され，各々の技術的進歩が胸部写真の臨床評 価を高めることにつながり，その事が医療のレベルアッ プに貢献して来た．この図式は将来も変らないと思われ る.

本シンポジウムに於ける演者の役割は(3)の読影技術に ついて，その過去を振り返りつつ現時点での胸部写真の 臨床評価に対する考え方を要約することにある。そのた めに社会的に重要視されて来た肺結核や珪肺と現代の課 


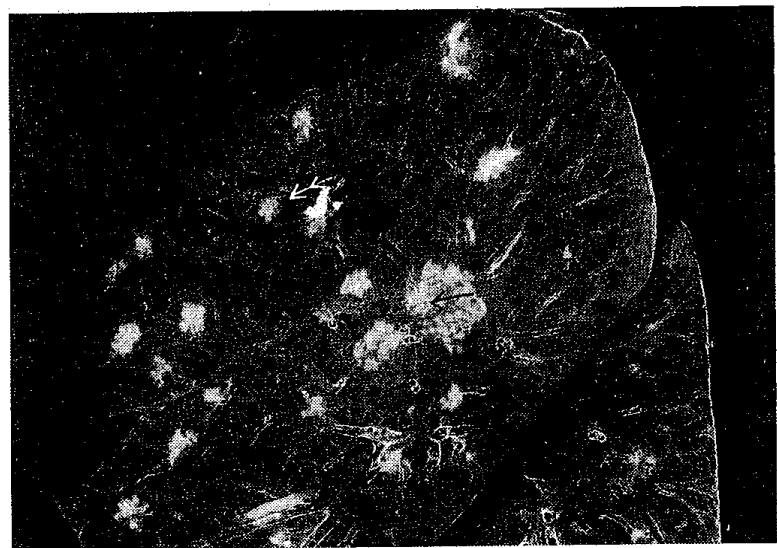

Fig. 1 Contact radiograph of lung slice with pulmonary tuberculosis. Small nodules produced by caseous nectosis are well recognized because of highrt contast against lung parenchyma $(\uparrow)$.

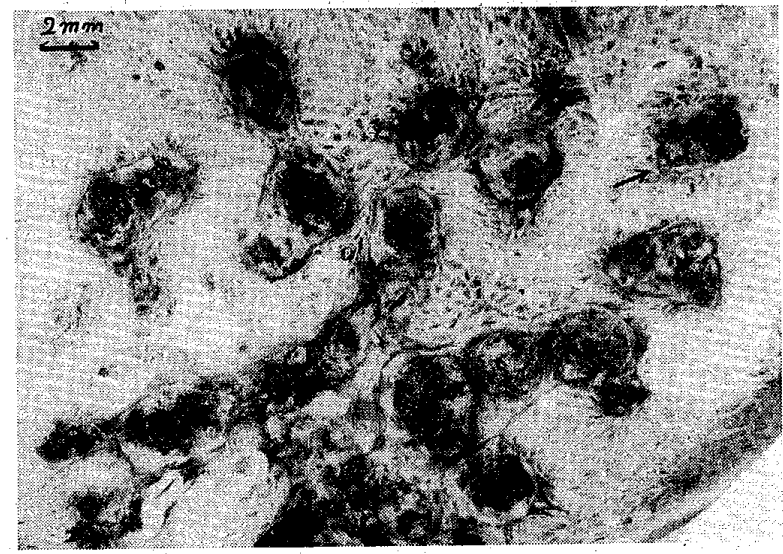

Fig. 2 Close up view of silicotic nodules. The nodules are sharply marginated from surrounding lung tissue.

題である肺癌や各種びまん性肺疾患に於て何が読影され, 又読影されようとしているかを述べる。この事を通して しか臨床評価の基準は明らかとならないだろうと考える からである。

\section{II . 各種肺疾患の $X$ 線病理学的特徵}

主要な肺疾患のX線病理学的特徵を標本に基づいて要 約する.

\section{(1) 肺結核症}

含気に乏しく緻密な壊死性乾酪物質が肺胞領域や細気 管支腔に充満する ${ }^{1)}$. 病変の大きさは肺葉全体から数 $\mathrm{mm}$ 大の粒状病変まで様々である，病変が棜小葉大に広 がると小葉間隔壁による境界が正常小葉との間で形成さ れる ${ }^{2)}$. 小さな粒状病変でも上記の特徴により病変と正 常部の境界は肉眼的，X線学的に明瞭である（Fig. 1)。

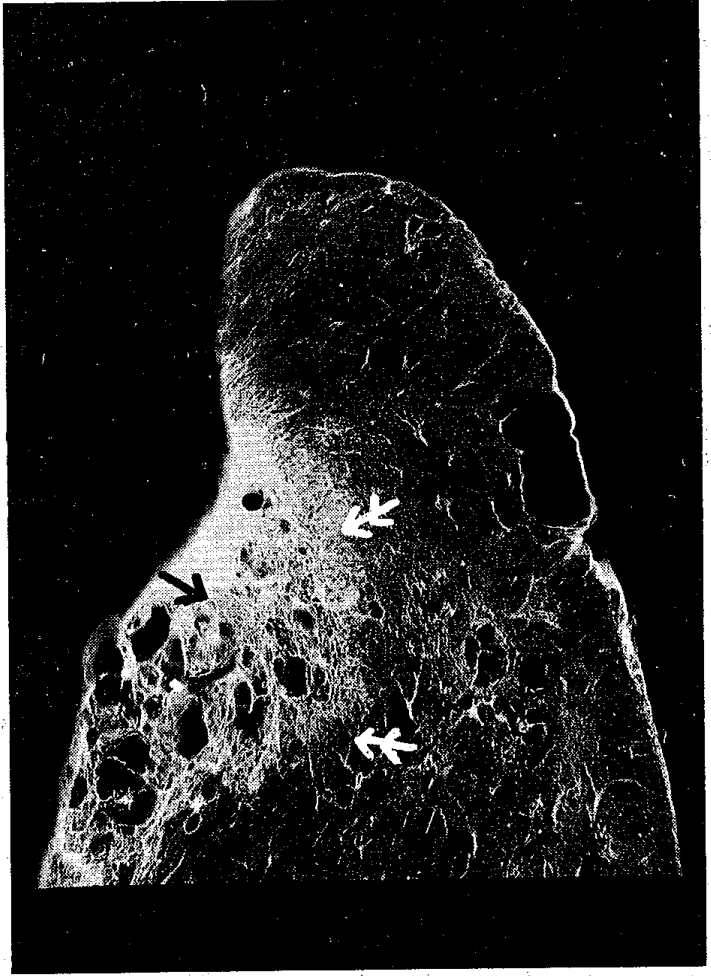

Fig. 3 Contact radiograph of adenocarcinoma of lung. Note central acarred area with strong radiopacity $(\uparrow)$ and ground glass density surrounding the scar $(\uparrow)$.

病変内にしばしば空洞が認められる。空洞は壊死物質が 気管支を通じて排出された結果形成される.

陳旧化すると収束傾向のある線維化病変が主体となり 瘢痕化し内部の気管支は拡張しつつ収束する。瘢痕内に 石灰化巣も多く見られる。

(2) 珪肺

炭粉沈着を伴なった黒色の硬い結節が肺末梢領域に分 布する (Fig. 2)．典型的結節は気管支・肺動脈系の末端 (小葉中心部) に形成される ${ }^{3)}$ この小葉中心部には呼気 細気管支が位置し, 珠肺に限らず多くの吸入性肺疾患が この領域に病変を形成し易い。

結節は線維組織から成り，必らずしも円形ではないが， 周囲肺とのコントラストは高い. 個々の結節が密集融合 して数 $\mathrm{cm}$ 大の塊状病変となることがある.

(3) 肺癌

代表的な肺癌である腺癌も扁平上皮癌を取り挙げる4). 腺癌は細気管支又は肺胞上皮から発生し，肺実質に囲 まれた弧立性の腫瘤を形成する。典型例では腺癌中央部 の線維組織を主体とし一部に癌巣を含む㗪痕と, 辺縁部 で癌組織が肺胞壁を置換するように進展する部分から成 る（Fig. 3）. 前者はその収束傾向のため近隣の気管支， 肺血管，肺胸膜を牽引する。一方後者内では癌と肺胞内 


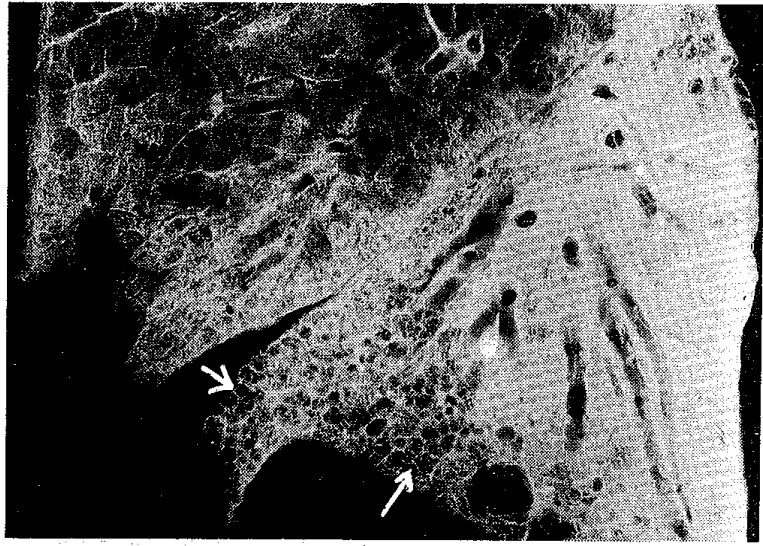

Fig. 4 Contact radiograph of pulmonary fibrosis. Honeycomb lung is recognized in the lower lobe $(\uparrow)$.

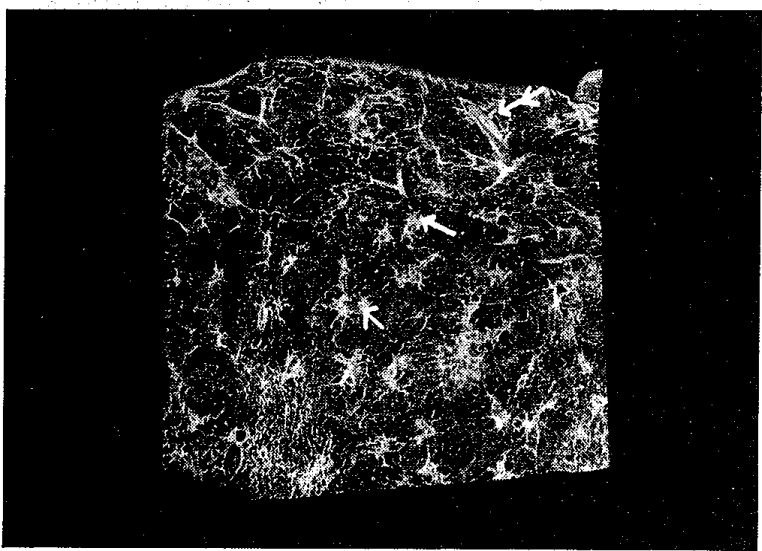

Fig. 5 Contact radiograph of lung specimens with diffuse panbronchiolitis. Small indistinct inflammatory nodules $(\uparrow)$ and dilated bonchiole with mucus $(\hat{\uparrow})$ are shown.

の含気が共存する。この事は腺癌の被写体コントラスト は内外層で異なることを意味する。

扁平上皮癌の多くが肺門近くの気管支に発生し，その 気管支を閉塞する．気管支の閉塞部位より未梢で無気肺， 閉塞性肺炎を来たすため腫瘤の大きさの割に以上の 2 次 変化がより広いということが起こり得る。

\section{(4) 肺線維症}

肺線維症は肺に線維化を来たす様々の疾患の総称であ るが，近年注目されているのは原因不明で慢性かつ不可 逆的に線維化の進行するタイプのものである. 病理学的 にはUIP (usual interstitial pneumonia) と呼ばれる5 UIP では胸膜側の肺を主体に線維化と，それに伴なう蜂 窝状肺が多く見られる (Fig. 4). 両肺を侵すびまん性疾 患であるが, 最近本症に高頻度に合併する肺癌が注目さ れている。

（5）びまん性沉細気管支炎

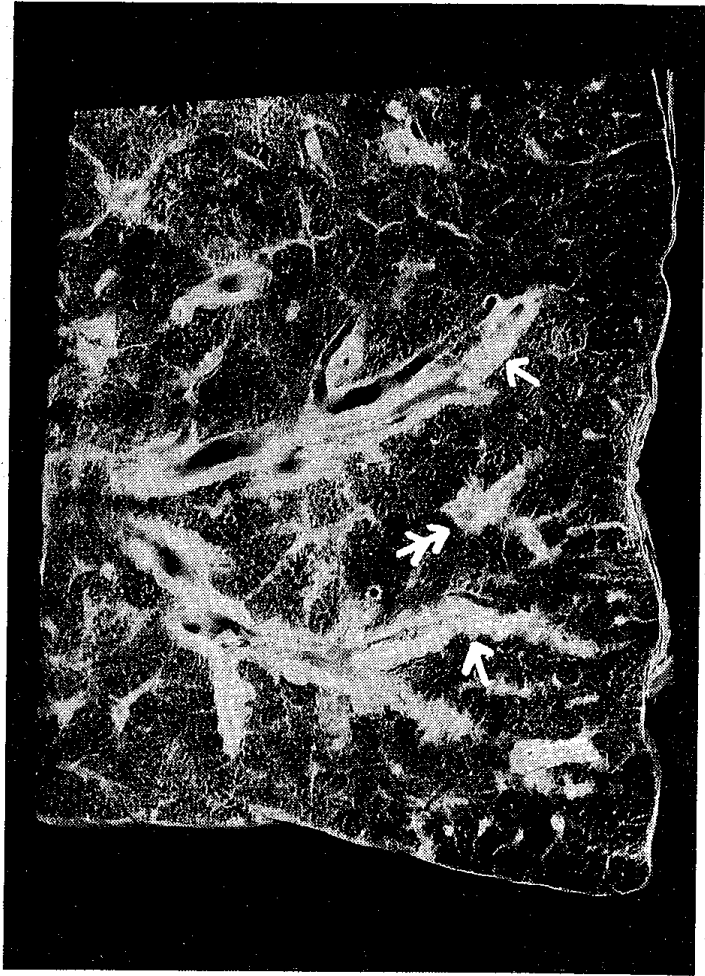

Fig. 6 Contact radiograph of lung slice with lymphangiosis carcinomatosa. Perivascular space of pulmonary artery $(\uparrow)$ and vein $(\hat{\uparrow})$ are markedly thickenned by tumors.

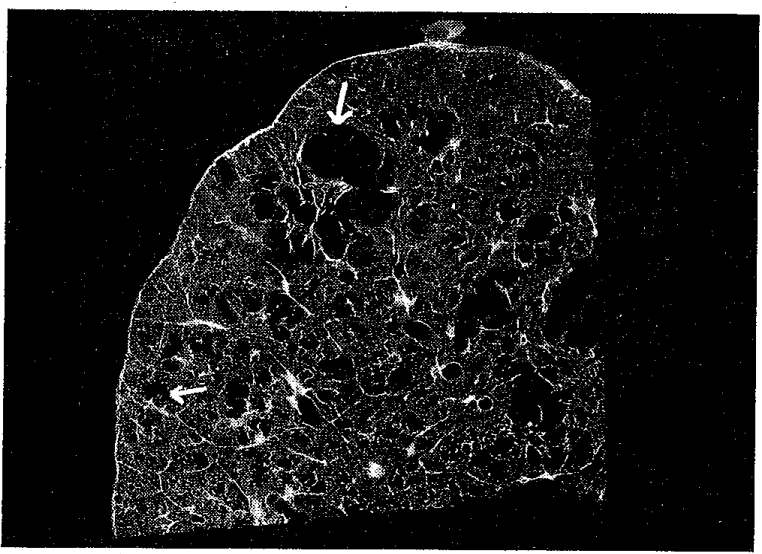

Fig. 7 Contact radiograph of lung slice with pulmonary emphysema. Small and large air cysts are recognized. The air cysts are not separated by fibrous septa from normal lung.

びまん性沉細気管支炎 (diffuse panbroncholitis, OPB）は我が国で提唱されたびまん性疾患である．珪肺 の場合以上に典型的に呼吸細気管支領域に炎症性粒状病 巣を形成する (Fig. 5)。より中枢側の細気管支, 小気管 支にも炎症が存在し気道拡張と拡張腔内に浸出物貯留を 認める。 
本症では病変が気道とその隣接肺に限局し，肺静脈と その周囲には病変がない6).

(6) サイコイドージス，癌性リンパ管症

どちらの疾患も肺のリンパ管が存在する構造である, 気管支，肺血管周囲組織，小葉間隔壁などを侵す（Fig. 6).サイコイドージスでは肉芽腫が, 癌性リンパ管症で は癌胞巣がこれらの構造に侵潤し肥厚させる ${ }^{6)}$.

（7）慢性肺気腫

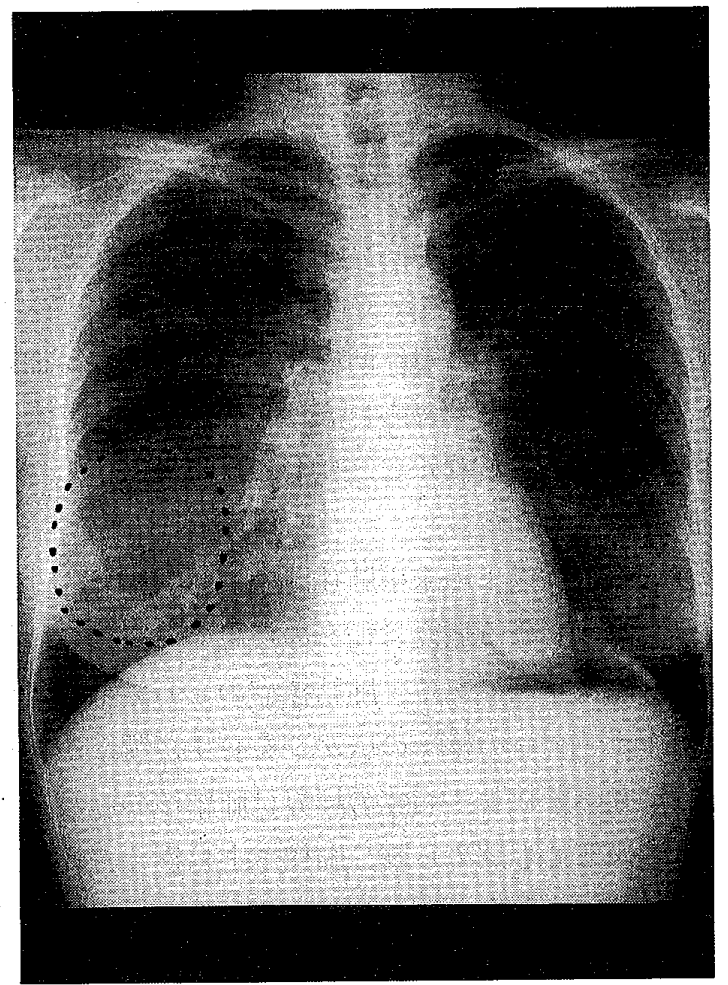

(a)

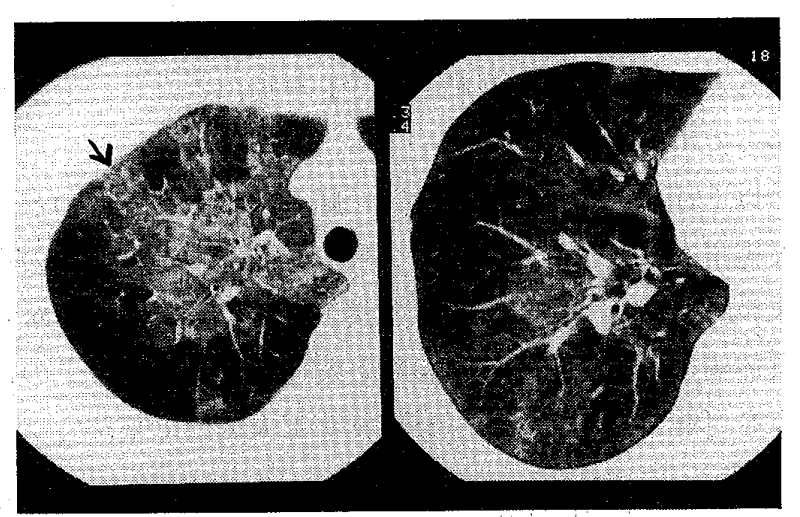

(b)

Fig. 8 (a) Chest radiogaph of hypersensitivity pneumonitis. Ground glass opacity is distributed throughout the lungs. The pulmonary markings are blurred by this opacity (circle).

(b) CT of the same case. The ground glass opacity is more apparent in $\mathrm{CT}$.
呼吸細気管支以下の肺構造が拡張破壊し, 肺血管の遺 残を含む大小の気胞が形成され7)る（Fig. 7）。䝟煙と密 接に関係し，気腫域には炭粉沈着が多い。個々の気胞は 健常肺との間で被膜を持たない.この事は肺気腫がX線 像でとらえ難い原因となっている。一般に中等症以上の 気腫でないとX線写真による診断は難しい.

（8）過敏性肺臓炎

過敏性肺臓炎の内，真菌に対するアレルギー反応で起 こる急性の夏型過敏性肺臓炎がX線診断学上興味が持た れる. 病変の特徵は細気管支から肺胞領域にかけての炎 症性細胞の漫潤である。この病変が両肺の広い領域に同 時に起こり，しかも肺胞含気が残されているためX線像 上一見軽微なスりガラス様影しか星さないことが多い (Fig. 8). 肺野濃度が不適切であったり粒状性の悪い写 真では見逃す可能性がある.

\section{III. 各種肺疾患の X線診断の変遷}

前章で取り上げた各疾患の特徵がX線像でどう把えら れたかを歴史的に考察する。全体として我が国の胸部X 線診断学は次の 3 つの要素を軸に発展したと言える。そ れらは

- 単純胸部 X線像

- 断層像

- 肺標本像

である ${ }^{6,7,8)}$. 特に肺標本とX線像の対比が診断学の進歩 に必要であるとの認識は古くからあり現在でもこの事は 変らない.この事を念頭に置き以下のように各時代を要 約する。

(1) 1960 年以前

肺癌が重要視される以前，社会的に注目されていた肺 疾患の代表が肺結核症と珪肺である。どちらの疾患も被 写体コントラストの高い微細病変を形成し ${ }^{6)}$, しかも病 変は肺結核症の一部を除いてびまん性である (Fig. 1， 2).

一方当時のX線像は感光材料や撮影機器の問題で以下 のような限界を有した。

- 低鮮鋭性

・低圧撮影のため観察範囲に限界がある

しかしこれらの限界は両疾患の高コントラスト，びま ん性という特徴により致命的となり得なかった。観察し 易い肋間隙で詳細な所見が取られ，この部分所見が疾患 の基本的特徴を表わすと考えたのは必らずしも誤りとは 言えなかった.さらに重要所見である石灰沈着が認識し 易いのは言うまでもない。 
（2） 1960 年以降〜 1970年代

(i) 肺癌

肺鶕の診断学が我が国で確立された時期が1960年以降 から1970年代である。病理，内視鏡，X線のそれぞれの 行野の診断学が肺標本と対比されながら整備された4).

X線唁断の方面では前章で述べたように，肺癌の発生 及び発育部位である末梢肺野と気道に焦点が絞られ，そ れらが盲点少なく描出されるX線像が必要となった，必 然的に高圧撮影が定着し, 機器の進歩もその要求に答え 得た。

断層撮影が有効に利用されたのも肺癌X線診断学の特 徵である ${ }^{4,6)}$. 断層像で腫瘤の特徴のみならず関与する気 管支, 肺血管に肺癌, 特有の所見が見い出された.これ らの成果は断層像と肺標本を $1 ： 1$ で対応させることに よりもたらされたものである。

(ii) その他の疾患

肺癌のX線診断技術の確立とほぼ同じ時期に他のびま 乙性肺疾患の臨床的研究が行なわれた，肺線維症, びま ん性汎細気管支炎はその代表でありそれらの病理像， $\mathrm{X}$ 線像, 臨床像が究明された (Fig. 4,5)。X線診断では肺 癌の場合と異なり断層像は余り重要視されなかった. 断 層像の解像力ではびまん性病変の形態学的分析は難しか ったからである. その替り, 単純X線像と肺標本の対比 が主として行なわれた. 単純X線像は撮影機器と感光材 料の進歩により以前より高鮮鋭度のものが得られるよう になった. しかしながら単純X線像と病理像のギャップ は大きく, 前者が病理所見をどう反映しているか充分に は解明できなかった。 その最大の理由が単純X線像に於 ける像の重複生成の未解明にあった。

断層撮影による解析が有効であった例外的びまん性疾 患がサルコイドージスと癌性リンパ管症である（Fig. 6).これらの疾患では断層像で充分解析できる比較的太 い気管支と肺血管にも病変が存在することが確認され $た^{6)}$. この読影技術は肺結核, 肺癌で応用かつ確立された 区域解剖学的見方の延長にあり，当時世界に例を見ない 業績であった。

(3) 1980年以降

1970年代前半に CT が発明された：当時の CT は解像 力に限界があり, 肺野の CT (以後肺 CT) が断層像や単 純X線像に優るとは見なされず，その臨床的価值は不明 であった.

ところが1979年から1980年にかけて高解像度 CT (以 後は単にCT と呼ぶ）が開発され，肺野病変の解析に新 しい時代が開かれた6). 肺 CT は解像性, 濃度分解能共に
通常断層法に優るため特に微細病変の描出に適し，その 像は肺標本の肉眼像に極めて近いことが標本との比較検 討で分かりつつあり，この方面の我が国の研究レベルは 高い.

我が国で肺 CT が最初に成功を納めたのは以下の病変 であり，世界に先駆けて発表された。

\section{(i) 練気管支病変}

細気管支は直径 $1 \mathrm{~mm}$ 以下の極めて簿い壁より成る 空気を含む管腔構造であるためその正常像はCTでも捉 えられない.ししかしびまん性沉細気管支炎 (Fig. 5) に侵 された細気管支は CT で認識可能である.

(ii) 肺血管周囲組織の病変

特にサルコイドージスに於て未梢肺血管の周囲組織内 に肉芽腫が形成され，血管影が肥厚する所見が明暸に捉 えられたのは画期的進歩であっだ). 癌性リンパ管症 (Fig. 6) でも同様である. 断層像では比較的太い血管に ついて以上の所見は認められたが，CTによって未梢ま で可視範囲が広げられたことになる。

(iii) 肺胞領域の病変

呼吸細気管支以下の末梢肺(肺胞管, 肺胞のう, 肺胞) に浸出物が充満する病変は種々の疾患で見られる。肺結 核症はその代表例である。肺結核症の CT では「 $\mathrm{mm}\lrcorner$ か ら「 $\mathrm{cm}_{」}$ オーダーの様々の広がりを有す浸潤影が見られ る. 小葉間隔壁による病変の境界は肺結核のみならず他 の肺胞性病変でも認められ, 肺標本上は極く普通の所見 であるが，臨床画像上で捉えられたのは CT が始めてで ある².

肺線維症に見られる蜂窩状肺 (Fig.4)もCT で明確に 診断される. 標本との対比で $2 \mathrm{~mm}$ 程度ののう胞の集合 からなる微細な峰嗝状肺でも CT で検出されることが分 かった

以上述べた微細病変とは別に肺 CT はそれまでのどの X線学的手法より鮮明に肺の外形を描出し得た。その結 果単純 $\mathrm{X}$ 線像でぞの領域が観察上の亘点になり易いかが 具体的に理解され，肺癌診断と関連しながら観察上の盲 点を可能な限り減らす写真作りが工夫されて来た7).

\section{IV．単純胸部 X線写真の臨床評価の指標}

我が国の肺疾患のX線診断学は高コントラストである が微紐病変を有す肺結核と珪肺, 見落しが許されない肺 癌に代表される肺野及び中枢部気道内の弧立性結節，そ して病変としてはコントラストの必らずしも高くない肺 線維症やびまん性沉細気管支炎などのびまん性疾患を経 験した. そしてその底流にはX線像は肺内の病理解剖学 
的立体像の反映であるという考え方がある．そのためよ り正確な病理解剖学的立体像を得るため肺標本を積極的 に解析することが勧められた。しかし病理解剖学的立体 像はX線像と同じものではなく両者の間にはギャップが 存在する.ギャップの原因として次の 3 つが考えられる.

(i) 病理解剖学的立体像の未解明……これは読影医の 責任に於て追求されねばならない.

(ii) X線像の画質……濃度設定，コントラスト，鮮鋭 度，粒状性が不充分。

(iii) $\mathrm{X}$ 線像の重複生成……既存構造と病変, さらに病 変同志の重なりに起因する病理解剖学的立体像の不明確 化.

(ii)，(iii)は画像作成技術に深く関係している. (iii)の本質的 解明は未だなされておらず，とりあえず重複を回避する 手段としてかつては断層撮影が，そして現在はCTが使 用されている6). 読影は読影者の蓄積された病理解剖学 的立体像とX線像を関連付ける高度認識活動であり, 読 影者はこの両方に充分な知識と経験を有さなければなら ない.しかしこれだけでは不充分で, 先に挙げたギャッ プの原因の中で(ii)，(iii)に対する技術的なサポートが必要 であり,これらが揃って始めて有効な読影行為が成り立 つ.この意味で放射線技師も読影に参加すべき理由があ る.

以上の事柄を踏まえX線写真の臨床評価の指標は, 主 要な標的臟器を胸部の中でも肺と明解に定めつつ以下の 2 つに整理されるだろう7).

(1) 肺の微細な構造と病変が認識できる.

(2) 肺の外縁及び中枢部気道が認識できる.

これらは技術的に，二律背反的な面があり，現在でも 充分に実現されているとは言い難い.

肺の微細構造の代表が末梢肺血管である. 正常者では 肺血管影の辺縁は鮮鋭であるが，血管周辺の肺胞領域の 病変如何んではコントラストが低下ししかも血管影の辺 縁が平滑でなくなる。この肺野濃度と肺血管影の関係は 特にスリガラス影と呼ばれる陰影を主体とする疾患, 例 えば過敏性肺臓炎,で微妙であり病変の実在に関して読 影者と技師相方からの検討が必要である. 病変の広汎さ にも拘らずその存在診断が難しい別の疾患が慢性肺気腫 である (Fig. 7). 特に CT で肺気腫の存在が明らかにも 拘らず胸部写真が正常であることは日常良く経験される. 老令人口の増加と共に慢性肺気腫は多くなっており,こ の慢性疾患の骖断とフォローに適したX線像の画質追求 のノウハウは他の疾患に有用であろうと考えている.

肺外縁及び中枢部気道が認識できることは肺癌診断で
重要なことであり，このために胸部中心部を主体とした 感度補償の技術が導入され成果を挙げた。しかし低濃度 部に於ける適正コントラストは縦隔に限らず，広沉な病 変を有する肺野でも必要とされる.この解決法として “C”ないし“L”タイプの感光材料が開発されそれなりの 成果を上げたが，逆に微細な既存構造や陰影が認識し難 くなる問題が生じ, 胸部写真の難しさが実感される結果 となった.

\section{V. まとめ}

胸部X線写真の臨床評価の基準は扱かう疾患, 利用で きる機器や撮影技術レベル, 撮影対象の病理解剖学的構 造に対する認識の深さによって変わる. その事を考虑し てより良い胸部写真を作るにはどうすべきかを筆者なり に以下のようにまとめた。

(1) 胸部 X線写真の長所と短所が肺 CT との対比でよ く分かるようになった. 即ち, CT の特幑である重なりが 最小限に抑えられ，高いコントラスト分解能を有する画 像が得られるという点が胸部X線写真に欠けている事は

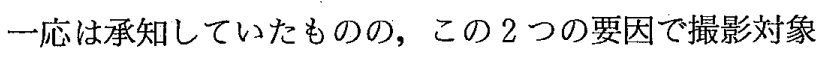
の実体がこれほどまでに分かり難くなるとは予想できな かった.そこで, 胸部X線写真には先ず適正な濃度と細 かなコントラストがいかに重要であるかが理解できた. 次に全ゆる投影像に於いて不可避な像の重複生成の問題 につき我々はほとんど追求できていなかったことを逆に CTによって教えられた。一方, 胸部写真の長所は全体を 概観できることにあるが，最新の CT は連続簿切スライ スから全体像である 3 次元画像を目指しており, 肺 CT はある意味で胸部X線像に近づきつつある。これを言い 替えると肺 CT と肺の Digital Fluoroscopy はそれぞれ の究極の姿では多くの共通点を持つと予想される。そし て胸部X線像の重複生成の問題は CT と OF の技術によ りやっと解答が得られる時代になったと言える。

(2) 胸部X線写真の難しさは肺が存在する全ゆる領域 に於て広い濃度域をカバーせるばならないことである。 それでないと骨〜軟部組織に重なる正常肺や結節を認識 するのが難しいし，さらに観察が容易とされる中鎖骨線 領域の斾病変でさえその中に存在する粒, 線, 網, 石灰 化，空洞等とそれらの背景にある含気が診断できないこ とになる。これらの事を追求するのに適した（言わば撮 影技術を磨くのに良い）疾患の代表を挙げると

(i) 病変が広沉にも拘らず存在自体が問題となる夕イ プの疾患としてびまん性肺疾患では, 中等度以下の慢性 肺気腫, 過敏性肺臓炎であり, 弧立性病変なら $1 \sim 2 \mathrm{~cm}$ 
大の小型肺癌であろう。

(ii) 病変の存在は明らかであるが, 病影の詳細を知る 必要がある疾患としては肺結核, DPB, 肺線維症が適当 であろう．陰影が微細だからであり，それほど稀な疾患 ではないからである。

(3) 撮影機器と感光材料の進歩によって胸部 X線像の 鮮鋭性と粒状性は過去に比して著しく向上した。両者の 向上は必らずしも被写体コントラストの大きくない病変 が狭い空間で微細に展開する場合に，病変領域で良好な コントラスト分解能を獲保する上で重要であろう。とこ ろで肺疾患の多くは肺野の濃度を低下させ，同時に肺血 管影のコントラストを低下させかつ血管影の辺縁を不鮮 明化させる。この辺の読影の正否には微妙な粒状性と鮮 鋭度の良し悪しが効いてくる。

こうなると, $\mathrm{X}$ 線写真全体と病変局所に於ける鮮鋭度 と粒状性に関する技師側のコメントを是非とも必要とす る.これは既に読影への参加である.

（4）訔い古された事とは言え肺標本の解析には胸部診 断学の進歩の原点であり，この事は過去も現在も変りな い. ただ画像のファイリングや 3 次元解析の機器が進歩 したため, 臨床のX線像や CT とのより密接な対比を考 慮して標本の扱かい方はそれなりの工夫を要するであろ う.

\section{謝辞}

今回のシンポジウムに唯 1 人の放射線科医として参加 し, 綿密な準備過程と熱心な討論を通して多大の貴重な 体験をさせて頂いた. シンポジストの方々, 座長の山本 義慧氏，さらに激励して下さった川上寿昭氏を始めとし
た愛媛県技術学会支部の各位に深甚の謝意を表します。

\section{文献}

1）岩崎龍郎．結核の病理．財団法人結核子防会，東京， 1976

2）伊藤春海, 金岡正樹, 野間恵之, 他. びまん性肺病 変の画像診断〜小葉性病変をめぐって〜，画像診断 $8: 562-571,1988$

3）中西 敬。珪肺症扔よび珪肺結核症の L 線像と病理 解剖学的所見の比較. 日本医放会誌19：800-818, 1959

4) Suzuki A and Nishiwaki Y. Lung Cancer Dicgnosis. A Roestgendogical Handbook. Kyowakikaku Tsushin, Tokyo, 1986

5）北市正則．原因不明のびまん性間質性肺炎の病理組 織学的分類とその臨床的意義. 最新医学 $47: 1271$ 1278, 1982

6）伊藤春海. 肺の高分解能 CT (HRCT) 呼吸 $10 ： 122$ $-137,1991$

7）伊藤春海. 胸部 $X$ 線診断のピットホール．日本放技 会誌47：1950-1961，1991

8）伊藤春海. 肺疾患におけるレントゲンと病理の比較 検討. Part 1，2. 日本放技会誌 $43 ： 589-600 ， 1708$ 1720,1987

9) Nishimura K, Kitaichi M, Izumi $T$ et al. Usual Interstitial Pneumonia: Histologic Correlation with High-Resolution CT. Radiology 182: 337342,1992 